\title{
Practical Utilization of ICT in Adult Language Learning: Challenges and Barriers
}

\author{
Hendro Saptopramono, M.Zaim, Syahrul.R, Agustina \\ Politeknik Negeri Padang, Universitas Negeri Padang-Indonesia \\ hendro.pnp@gmail.com
}

\begin{abstract}
English has become one of essential skills that must be acquired in this digital era. English learning process is not only conducted by young learner, but it is also conducted by adult learners. The development of technology especially Information Communication Technology (ICT) has lead significant improvement of learning process in the forms of method, materials, and media. This study investigated adult's perception in using ICT in their English learning process by using questionnaire. The data revealed that there were some essential devices of ICT that had been used such as internet, game and email. However, they also mentioned some barriers that could have limited their ability to use these devices optimally.
\end{abstract}

Keywords-ICT, Language Learning; Adult Learning

\section{INTRODUCTION}

English has become one of the most essential languages that is spoken by two third of human population. It is the reason why English is taught not only for children at their early age but for adult too. An "adult" can be identified as a person aged over 16 years (E Commission 2000b.) Therefore, adult learners are all the socially mature citizens who undertake and educational activity for educational activity for a variety of motives: personal, professional, economic, social, cultural, civic and spiritual (Jarvis, 1995). Adult learning has become one of essential topics that become a focus of current educational research. Knowles (1984) describes five characteristics of adult learners which make them differ from child learners. Firstly, adult learners have a self-concept. They have transformed their learning concept from dependent learning into a self-directed learning which is also called as independent or autonomous learning. Secondly, there is role of experience possessed by adult learners which accumulates a growing reservoir of experience to increase their learning resource. Thirdly, these learners have a ready phase to learn and to motivate their self to increase certain level of skill. Fourthly, they have shifted the orientation from comprehending knowledge to implementing a knowledge. Furthermore, the orientation has moved from one of subject-centeredness to one of problem-centeredness. Finally, they have internal motivation to learn.

In this 21 st century, the term "technology" is an important issue in many fields including education. This is because technology has become the knowledge transfer highway in most countries. Technology integration nowadays has developed through innovations and transformed our societies that has completely changed the way people think, work and live (Grabe, 2007). The rapid growth of the global economy and the information based society has pressurized education systems round the world to use ICTs to teach the knowledge and skills they need in the 21st Century (World Bank, 2004). According to Selwyn (2003), ICT is utilized to assist students to learn more effectively and help teachers to do administrative tasks more efficiently. Krajka (2002) explains that ICT has the potential to become communication tools since it can provide certain features such as emails, chat groups, discussion groups, pals ${ }^{\text {ee }}$ clubs and others to conduct activities which require collaboration. Vygotsky (1978) and Bruner (1996) believed that learners could learn actively and construct new knowledge based on prior experiences and as a result, instructor's role is to facilitate the learning process. According to Merriam, Caffarella, \& Baumgartner (2007), constructivism "is a process of constructing meaning; it is how people make sense of their experience". In the constructivist approach, an emphasis is placed on the development of learners"e ability and skills to bring about a solution to their real life problems and as such, there is a merge of problem-solving and free discovery skills. In essence, the process of knowledge acquisition is dynamic and built around the process of discovery (Dewey, 1916 as cited by Huang, 2002). The major thrust of constructivism is centered on learning, as such, it advocates a learner-centred learning environment rather that teacher-centred environment. In a learner-centred learning environment, learners are at the center of the learning experience and this can be aided in a multiplicity of ways. It has been observed that the primary key to constructing new knowledge is by engaging learners in an experienced-based learning and based on this, developing a learning experience that has the capacity to yield maximum benefits to learners requires the facilitator to be cognizant of individual learner's needs (Collins, 2008).

ICT as modern technology that simplifies and facilitates human activities is not only advantageous in many respects but also has many limitations. The limitations can be categorized as adult educators ${ }^{\text {ee }}$ related, adult learners ${ }^{\text {ee }}$ related and technology related. All of them potentially limit the benefits of ICT to adult education. Adult educators 
attitude plays an important role in the teaching learning process that utilizes computers and internet connections. Of course, some adult educators may have positive attitudes to the technology, but refrain from using it in teaching due to low self-efficacy, tendency to consider themselves not qualified to teach with technology. In this respect, Ormrod (2006) defined self-efficacy as the extent or strength of one"s belief in one's ability to complete tasks and reach goals. Adult educators ${ }^{e e}$ resistance and lack of enthusiasm to use ICT in adult education is also another limitation. Furthermore, many adult educators may not have the required Information and Technology (IT) skills and feel uncomfortable nor do they have trainings needed to use the technology in their teaching. This is a drawback to adult education curriculum enhancement, ICT teaching - learning process and overall academic success of the adult learners and institution.

\section{METHODS}

This study employed a survey design in order to measure the intention of adult learners use ICT for learning English. For the purpose of the study, 40 participants who were categorized as adult learners in Padang, Indonesia were involved. This study was conducted by using survey method. To elicit data for the study, the participants had responded to three parts of questionnaire: 1) Personal experience in learning English, 2) Experience in using ICT in learning English and 3) Problems that they face in using ICT to improve their English. Part 1 consisted of three open-ended questions that focus on exploring the experience of these adult learners in learning English. The second part consisted of two closed-ended questions that focus on types of ICT devices and duration of their utilization in learning English. The final part consisted of closed-ended questions that explore potential problems in using ICT for learning English.

\section{The Personal Experience in learning English}

\section{FINDING AND DISCUSSION}

Length of English learning among the participants shows some various answers. Majority of respondents (70\%) claim that they have learned English for about more than 10 years from the elementary school. Meanwhile, other respondents claim that they have less length of English learning because they started learning English at the secondary schools.

The participantsee occupations may also show some variations. There are twenty five participants working as lecturers with different background of teaching subjects. The other fifteen participants work as administration staffs with different positional level. Because they have different occupational background, the motivation that they have in learning may also show some variations.

Table 1. Motivation to Learn English

\begin{tabular}{llc}
\hline No & Motivation to learn English & Total respondents \\
\hline 1 & "I want to continue study overseas" & 25 \\
\hline 2 & "I want to communicate with others in English"e & 2 \\
\hline 3 & "I want to be able to understand English novel” & 3 \\
\hline 4 & "I want to travel abroad" & 5 \\
\hline 5 & "I want to pass English test with a good score" & 5 \\
\hline
\end{tabular}

Motivation plays essential role in learning English. There are many research and study that reveal this interrelated connection. Williams and Burden describe motivation as "a state of cognitive and emotional arousal, a state which leads to a conscious decision to act and gives rise to a period of sustained intellectual and/or physical effort" (1997:120). The is also described in different words which can be seen as "motivation" is a combination of effort plus desire to achieve a goal plus favourable attitudes towards the goal to be accomplished (Gardner, 1985). The existence of power relationships between languages is one of the reasons why people have favourable or unfavourable attitudes towards learning a particular language. English, as an international language, play vital roles in academic and business activity. Language learning motivation has been recently received research interest in EFL/ESL contexts (Zusho, Anthony, Hashimoto, \& Robertson, 2014). It is argued that an L2 learner with high motivation will be successful (Brown, 2007). In the same vein, Gardner (2010, p. 241) reports that "students with higher levels of motivation will do better than students with lower levels". Various studies have been conducted to observe how motivation influences onees learning process. Karahan (2007) investigated the dissatisfaction caused by learners, teachers, and parents showing that most of EFL students in Turkey cannot achieve the anticipated level of English proficiency. The findings revealed that in spite of exposing students to English in the school environment constantly, they had little affirmative attitudes. In addition, the participants conceived the value and significance of the English language but did not show high level inclination toward learning English. In another study, Vaezi (2008) examined Iranian undergraduate students ${ }^{\text {ee }}$ integrative and instrumental motivation toward EFL learning. It was found that Iranian EFL learners had high motivation and positive attitude toward EFL learning. They were also more instrumentally motivated. Tahaineh and Daana (2013), later, studied the motivation orientations (i.e., instrumental and integrative) of the EFL undergraduates and their attitudes towards 
English learning and its community. The results showed that learning English had the minimum effect on the studentse English language motivation, while the participants ${ }^{e c}$ attitudes toward the English community were highly positive.

In the Indonesian context, motivation for learners to learn English is very essential. In most study. Salikin et.al (2017) has revealed from their study about the motivation of Indonesian EFL learner's motivation in reading that the experiences of the EFL learners influence their intrinsic motivation in reading English texts. The learners who have more experiences in English reading have more desire to read the English texts. It will be easier for them to get involved to English texts than other who lack experiences. It is due to their knowledge in grammars and vocabularies than others who did not. This fact helps them much to understand English materials even such difficult English texts like journals which can challenge them. According to arguments above, it can be concluded that the learners who tend to read simple English texts can be said as the learners who were lacking English reading experiences. Yulia (2013) also discovers that for Indonesian EFL learners, the last particularly triggers their motivation to learn English is that English is as a global language that would be valuable for their future life. English is used as the passing standard for continuing higher education, for passing job interview and even for getting a job. Although the majority of Indonesian people who learn English fail to achieve the level of success as expected, there is a group of people who are quite successful in mastering the foreign language, so that they have got benefit and profit from it such as getting the proper job, getting the additional income, getting the increase of position, and getting the scholarship to study overseas like: USA, Australia, Canada, England, New Zealand and others.

The second question, ,how do you improve your English?" has been answered in different ways by the respondents. The following table shows the answers of the respondents.

Table 2. Way to improve English competency

\begin{tabular}{llc}
\hline No & The way to improve English competency & Total respondents \\
\hline 1 & "I improve my English by using computer application" & 25 \\
\hline 2 & "I try to watch English movie to add my vocabularies" & 2 \\
\hline 3 & "I read English novel to get more new words" & 3 \\
\hline 4 & "I want to travel abroad" & 5 \\
\hline 5 & "I want to pass English test with a good score" & 5 \\
\hline
\end{tabular}

It may be noticed that most of participants deals with technology devices to develop their English. Computer can be seen as the unlimited resources of lifelong learning and for the progression on to the next contextual learning program.

\section{Utilization of ICT in promoting English Learning}

There are three questions that become the focus in this section. Firstly, the respondents select certain devices of ICT that they use in learning English. There are about twenty types of ICT devices that are commonly used in language learning such as the internet, language laboratory, mobile phone, podcast and others. Among these devices, there are five devices that are claimed to be used more frequently by respondents. They are websites that provide English learning materials. Secondly, social media like facebook, instagram and whatsapp are used by the respondents to learn English. Thirdly, the respondents also mention the computer application, especially the English test and other. Fourthly, online dictionary is commonly used to accompany them to learn English.

The second question explores about duration of their utilization can be divided into four classification. It indicates that the participants used to study more than eight hours per week. This length of studying time can be associated with the benefits that they get from learning by using ICT.

Table 3. Benefit of Using ICT

\begin{tabular}{lll}
\hline No & \multicolumn{1}{c}{ The benefit of using ICT } & Total Respondents \\
\hline 1 & It can be used to find a new friends & 5 \\
\hline 2 & It is more convenient to learn by using ICT & 17 \\
\hline 3 & It is easier than the conventional learning method & 5 \\
\hline 4 & It is useful to learn new vocabulary & 3 \\
\hline 5 & It is more fun & 3 \\
\hline 6 & It is more attractive than learning by using book & 3 \\
\hline 7 & I can choose my own learning way & 4 \\
\hline
\end{tabular}

Basically, learning English by using ICT has provided many benefits for the leaners. Lee (2001) believes that the integration of technology in language learning can help students to improve and change students ${ }^{\text {ee }}$ learning attitudes and boosting their self-confidence. Along this line, Galavis (1998) and Dunken (1990) assert that the use of technology enhances learners ${ }^{\text {ee }}$ language proficiency and their overall academic skills. 
Students are more likely to display positive attitudes when computers are used in the classroom. They are more motivated and interested to communicate with native speakers from other countries ( Warschauser,1996). The use of ICT may provide a learning environment where motivation is maintained and enhanced. The investigation of the impact of technology use in EFL classrooms has shown that EFL effective activities can be enhanced by means of technology. Students insisted that their teachers should use technology in the classroom. This has increased and maintained their motivation and engagement and involved them more in the learning process (Ilter, 2009). The use of blogs, podcasts and digital videos as class content increases motivation and engagement in the language classroom. Jay (2006) investigated the use of blogs to motivate students to write; and demonstrated the importance of giving students a true audience and the utility of writing for a global audience as well. Mc Minn (2008) from the Hong Kong University of Science and Technology has chosen to explore the impact of podcasting on students ${ }^{\text {ee }}$ motivation in the language classroom. He has concluded that podcasting, the publishing of audio or video files via the Internet, helps teachers make maximum benefits of classroom time through the use and integration of authentic material and simulated environments in the foreign language learning curriculum. The use of podcasts provides motivating authentic learning material. Podcasts, he continues to argue, give learners more opportunities to hear speech from the particular social group that they wish to learn about and perhaps identify with. One more study devoted to the investigation of the effectiveness of using ICT to enhance motivation in the language classroom is the one conducted by Kassim et al (2007). She found that the use of ICT in language classes allows students to develop positive attitudes towards language learning. Most participant students believe ICT motivates them in gaining more interest in the learning process. By increasing the amount of authentic material in the classroom (blogs, podcasts, and digital videos) and providing students with appropriate skills to approach authentic material, teachers promote meaningful interaction, raise students ${ }^{\text {ee }}$ interest and motivation; and ensure more participation and engagement in the classroom

Furthermore, utilization of ICT in language teaching such as, Computer-Assisted Language Learning (CALL) fosters learners ${ }^{\text {ee }}$ autonomy and helps them develop individual learning strategies (Murray et al, 2005). A critical factor in the success of the experience is the change of culture among students, teachers and parents. A teacher is no longer expected to be the only provider of knowledge in the classroom and students are required to play a new role. They need to take ownership of their learning and contribute to its construction and organisation ( Lee, 2005).

ICT also provides efficient way to learn English because learners do not have to spend their time or the money to travel and learn from students in other parts of the world. A simple Internet video or audio link can allow language users to exchange information and ideas, discuss issues and engage in authentic conversations and exchanges Rank et al, 2011). Technological innovations and the web in particular have not only the potential to enhance the quality of education, but can create new learning spaces and facilitate interaction as well (Lee, 2005). Chapelle (2003) argues that computer-mediated communication "constitutes a kind of virtual immersion setting for those who choose to participate in it" (p.35). In keeping the common wisdom suggesting that if one wants to learn English, they should go live in a place where English is spoken, many Internet websites for communication among English learners offer opportunities for conversation and interaction with other English speakers. New technologies also have the potential to transform task-based language teaching into active learning by bringing students together to communicate, interact and construct knowledge (Thomas, 2011). According to Gillespie (2006), new technology enables students to collect information and interact with resources, such as images and videos. Murphy (2006) states that the Internet can serve not only as a reference source but also as a means of communication. It is argued that technology enables the user to get connected to the world outside of the classroom and hence produce high-quality work, knowing that their work will be viewed by a large audience.

Another advantage of technology is its potential for lowering anxiety among learners (Chapelle 2003, Levy 1997). In an exploration of EFL teachers' perceptions of CALL, Ozerol (2009) selected 60 language teachers, from various schools in Turkey. These teachers commonly agreed that technology lowered students' language learning anxiety whilst giving them more opportunity to communicate. Braul (2006) has discovered that using computers in language classrooms brought variety into the classroom atmosphere, developed learnerse particular language skills and increased learner autonomy. Moreover, Abdallah et al (2009) argues that the Internet is used in education because it facilitates learning, teaching and communication. It is possible to find a great deal of (course/subject) information online and to do so any time. Specifically commenting on advantages of the Internet for English Language Teaching, he mentions that students can study any topics in English independently online, and they can also find many activities on the Internet to use in order to improve their proficiency

\section{Barriers in utilization of ICT in language learning}

In this section, there are six types of potential barriers that might be faced by adult learners in utilization of ICT. These barriers include insufficient facilities, insufficient knowledge to work with the technology, unskillful teachers, lack of confidence in using ICT, lack of self motivation and lack of English proficiency. These findings are quite similar with other research studies have reported a number of barriers/obstacles teachers experience in using ICT in their classrooms. These include lack of resource access, inadequate training opportunities, lack of confidence amongst among 
teachers, paucity of time, insufficient knowledge about integration of ICT in lessons, technical issues, poor administrative support and poor fit with the curriculum. Barriers must be first identified, and then only actions can be taken to overcome those (Nikolopoulou \& Gialamas 2013). Copley and Ziviani (2004) identified barriers such as inadequate staff training, negative staff attitudes towards ICT usage, dearth of funds, impediments in procuring and managing ICT equipment, insufficient planning and assessment processes and lack of time. Inadequate technical support toward ICT at schools and lack of required access to internet were also identified as major impediments to the integration of ICT into curriculum as stated by (Salehi \& Salehi 2012).

\section{CONCLUSION}

The participantse perceptions on the integration of ICTs in their indigenous communities show the usefulness of ICT in adult learning of English. Findings show that participants hold positive views in regards to the tablets integration in their communities. Various consequences resulted from the integration of the tablets in the indigenous communities. To have easy access to knowledge and information, the inclusion of the communities in the digital culture and cooperative interactions among family members around the use of the tablets are some of the examples of these consequences. However, this study found that participants perceived several constraints and consequences of the ICTs integration in their communities that are related to the perceived negative extensive effects of the use and/ or misuse of ICTs by members in the community, which might endanger indigenous cultures and worldviews. However, In spite of the numerous benefits of using ICT to mediate the teaching and learning process in adult literacy programmes, there are still some attendant challenges as witnessed by the participants. While some had an issue with internet access, some others complained of insufficient facility and the financial burden it places on them. Importantly, the study identified the needed support that can enhance the effective use of these tools for instruction in adult literacy programmes.

\section{References}

Abdallah, A. N, et. al (2009). "The Effect of Computer Assisted Language Learning in Teaching English Grammar on the Achievement of Secondary Students in Jordan." The International Arab Journal of information Technology 6 (4). P 431-439

Binalet, C. B., \& Guerra, J. M. (2014). "A Study on the Relationship between Motivation and Language Learning Achievement among Tertiary Students.” International Journal of Applied Linguistics and English Literature, $3(5), 251-260$.

Braul, B. (2006). "ESL Teacher Perceptions and Attitudes toward Using Computer-Assisted Language Learning (CALL): Recommendations for effective CALL practice" MA Dissertation, Department of Secondary Education, Edmonton, Alberta

Brown, H. D. (2007). Principles of language learning and teaching. White Plains, NY: Pearson Education.

Bruner, J. (1996). The Culture of education. Cambridge, MA: Harvard University Press.

Chapelle, A. C. (2003). English language learning and technology. Amsterdam: John Benjamins publishing Co.

Collins, S. R. (2008). Enhanced Student Learning Through Applied Constructivist Theory. Retrieved May, 2016, from http://www.kpu.ca/sites/default/files/Teaching andLearning/TD.2.2_Collins_Applied_Constructivist_Theory.pdf

Copley, J. and Ziviani, J. (2004). "Barriers to utilisation of Assistive Technology with Children who Have Multiple Disabilities." Occupational Therapy International, 11(4), 229-43.

Dashtizadeh, P and Farvardin, M.T. (2016). "Relationship between Language Learning Motivation and Foreign Language Achievement as Mediated by Perfectionism: the Case of High School EFL Learners." Journal of Language and Cultural Education, 4 (3) 86-102

Dordi-nezhad, F. (2015). Construction, Validation and Reliability of the Foreign Language Attitude and Motivation Questionnaire. Language Related Research, 6(2), 107-128.

Dornyei, Z. (2005). Teaching and researching motivation. Beijing: Foreign Language Teaching and Research Press.

Fahim, M., \& Noormohammadi, R. (2014). "An Investigation into Perfectionism as a Moderator of the Links between Language Learning Styles and Strategies.” Journal of Language Teaching and Research, 5(5), 1121-1131.

Fatehi, M., \& Akbari, O. (2015). "An Experimental Analysis of Errors in Light of Language Learning and Language Use and the Role of Executing Involvement to Increase Motivation in the English Language Classroom." International Letters of Social and Humanistic Sciences, 51, 82-88.

Frost, R., Marten, P., Lahart, C., \& Rosenblate, R. (1990). "The dimensions of perfectionism." Cognitive Therapy and Research, 14(5), 449-468.

Galavis, B. (1998). „Computers and the EFL Class: Their Advantages and a Possible Outcome, the Autonomous Learner', English Teaching Forum, vol. 36, no.4, 27. http://exchanges.state.gov/forum/vols/vol36/no4/index.htm

Gardner, R. C. (1985). Social psychology and second language learning. London: Edward Arnold. (2010). Motivation and second language acquisition. NY: Peter Lang. 
Ghorban, D, F., \& Farjadnasab, A. H. (2013). "Examination of the Relationship between Perfectionism and English Achievement as Mediated by Foreign Language Classroom Anxiety." Asia Pacific Education Review, 14(4), 603- 614.

Gillespie, H 2006, Unlocking learning and teaching with ICT: Identifying and overcoming barriers. London: David Fulton.

Grabe, M., \& Grabe, C. (2007). Integrating technology for meaningful learning (5th ed.). Boston: Houghton Mifflin

https://www.researchgate.net/publication/305827833_The_Use_of_Two_ICT_Tools_in_Adult_Literacy_Programmes_ Lessons_Learned [accessed Jun 11 2018].

https://www.duo.uio.no/bitstream/handle/10852/49738/Viviana-Daza-Ma--thesis.pdf?sequence=1

https://www.researchgate.net/publication/305827833_The_Use_of_Two_ICT_Tools_in_Adult_Literacy_Programmes_ Lessons_Learned

http://www.iosrjournals.org/iosr-jrme/papers/Vol-6\%20Issue-4/Version-2/K0604026265.pdf

https://www.duo.uio.no/bitstream/handle/10852/49738/Viviana-Daza-Ma--thesis.pdf? sequence=1

Huang, H-M. (2002). "Toward constructivism for adult learners in online learning environments." British Journal of Educational Technology, 33(1), 27-37.

IBM Corp, Released. (2012). IBM SPSS Statistics for Windows, Version 21.0. Armonk, NY: IBM Corp.

Ilter, B.G., (2009). Effect of technology on motivation in EFL classrooms. Turkish Online Journal of Distance Education, 10 (4), Art. 9

Jarvis, P. (1995). Adult and continuing education: theory and practice. London: Routledge

Jay D. A. (2006). Motivating for writing through blogs. A Master thesis submitted to the Graduate College of Bowling Green State University. Available online at http:// etd.ohiolink.edu

Karahan, F. (2007). Language attitudes of Turkish students towards the English language and its use in Turkish context. Journal of Arts and Sciences, 1(7), $73-87$.

Knowles, M. et al (1984) Andragogy in Action. Applying modern principles of adult education, San Francisco: Jossey Bass.

Kassim, H. \& Zuraina, A. (2007). The Use of ICT in the implementation of student-centred learning (SCL). Internet Journal of e-Language Learning \& Teaching, 4 (1). pp. 15-31.

Krajka, J.G. (2002). Using the internet in the language classroom to foster learner independence? Ideal \& reality. Retrieved August 15, 2008, from http://www.iatefl.org.pl/tda/n/krajka.htm.

Lee, K. W (2000). English teachers ${ }^{\text {ee }}$ barriers to the use of computer-assisted language learning. TESL Journal, 6, (12). http://iteslj.org/Articles/Lee-CALLbarriers.html

Levy, M. (1997). Computer-assisted language learning: Context and conceptualization. Oxford University Press, Oxford

LoCicero, K. A., \& Ashby, J. S. (2000). Multidimensional perfectionism in middle school age gifted students: A comparison to the general cohort. Roeper Review, 22(3), 182-185.

McMinn, S. (2008). Podcasting Possibilities: Increasing Time and Motivation in The Language Learning Classroom. European Institute for E-Learning. Learning Forum 2008, 212-215.

Merriam, S., Baumgartner, L., \& Caffarella, R. (2007). Learning in Adulthood: A comprehensive guide. San Francisco: Jossey-Bass.

Murphy, C/ (2006). The impact of ICT on primary science (in P. Warwick, E. Wilson \& M. Winterbottom), Teaching and Learning Primary Science with ICT, Open University Press, Berkshire, England

Murray, D. E., et al (2005). Information technology and innovation in language education. In Davison, C. (E.d.) Hong Kong: Hong Kong University press.

Nikolopoulou, V. and Gialamas. (2013) Investigating pre-service early childhood teachers ${ }^{\text {ee }}$ views and intentions about integrating and using computers in early childhood settings: compilation of an instrument. Technology, Pedagogy and Education, 2 (18) pp. 201-219

Ormrod, J. E. (2006). Educational psychology: Developing learners. Upper Saddle River, NJ: Pearson Merrill Prentice Hall.

Ozerol, G. (2009). Perceptions of EFL primary school teachers towards CALL. MA thesis, Cukurova University, Turkey

Pishghadam, R., Akhondpoor, F. (2011). Learner perfectionism and its role in foreign language learning success, academic achievement, and learner anxiety. Journal of Language Teaching and Research, 2(2), 432-440.

Preacher, K. J., \& Hayes, A. F. (2008). Asymptotic and resampling strategies for assessing and comparing indirect effects in multiple mediator models. Behavior Research Methods, 40, 879-891.

Ram, A. (2005). The relationship of positive and negative perfectionism to academic achievement, achievement motivation, and well-being in tertiary students (Masteres thesis, University of Canterbury, New Zealand). Retrieved from http://ir.canterbury.ac.nz/bitstream/handle/10092/1300/thesis_fulltext.pdf ?sequence $=1 \&$ is Allowed $=\mathrm{y}$ 
Rank, T., et. al. (2011). Teaching English using ICT: A Practical Guide for Secondary School Teachers. New York, NY: Continuum International Publishing Group

Rice, K. G., \& Slaney, R. B. (2002). Clusters of perfectionists: Two studies of emotional adjustment and academic achievement. Measurement and Evaluation in Counseling and Development, 35(1).

Salikin, et.al. (2017). The Indonesian EFL Learners "e Motivation in Reading. English Language Teaching, 10(5), 81-90.

Schuler, P. (2000). Perfectionism and gifted adolescents. Journal of Advanced Academics, 11(4), 183-196.

Selwyn, N. (2003). Apart from Technology: Understanding People's Non-Use of Information and Communication Technologies in Everyday Life. Technology in Society, 25, 99-116.

Shams, M. (2008). Studentse attitudes, motivation and anxiety towards English language learning. Journal of Research and Reflections in Education, 2(2), 121- 144.

Shrout, P. E., \& Bolger, N. (2002). Mediation in experimental and nonexperimental studies: New procedures and recommendations. Psychological Methods, 7(4), 422-445.

Slaney, R. B., Rice, K. G., Mobley, M., Trippi, J., \& Ashby, J. (2001). The revised almost perfect scale. Measurement and Evaluation in Counseling and Development, 34, 130-145.

Tahaineh, Y., \& Daana, H. (2013). Jordanian undergraduates ${ }^{\text {ee }}$ motivations and attitudes towards learning English in EFL context. International Review of Social Sciences and Humanities, 4(2), 159-180.

Thomas, M. (2011). Task-based Language Teaching and Collaborative Problem solving with Second Life: A Case Study of Japanese EFL Learners. Proceeding at International Conference "ICT for Language Learning". University of Central Lancashire (United Kingdom).

Vaezi, Z. (2008). Language learning motivation among Iranian undergraduate students. World Applied Sciences Journal, 5(1), 54-61.

Vygotsky, L. S. (1978). Mind in society: The development of higher psychological processes. Cambridge, MA: Harvard University Press

Warschauer, M. (1996). Computer-assisted language learning: An introduction. In S. Fotos (Ed.), Multimedia Language Teaching (pp. 3- 20). Tokyo: Logos International.

Williams, M., and Burden, R. (1997). Psychology for language teachers. Cambridge University Press.

World Bank, (2004). Contributions of icts economic growth. Washington DC: The World Bank Institute

Yulia, Y. (2013). Teaching Challenges in Indonesia: Motivating Students and Teachers ${ }^{\text {ee }}$ Classroom Language. Indonesian Journal of Applied Linguistics, 3(1), 1-16.

Zusho, A., Anthony, J. S., Hashimoto, N., \& Robertson, G. (2014). Do video games provide motivation to learn? In F. C. Blumberg (Ed.), Learning by playing: Video gaming in education (pp. 69-86). NY: Oxford University Press. 